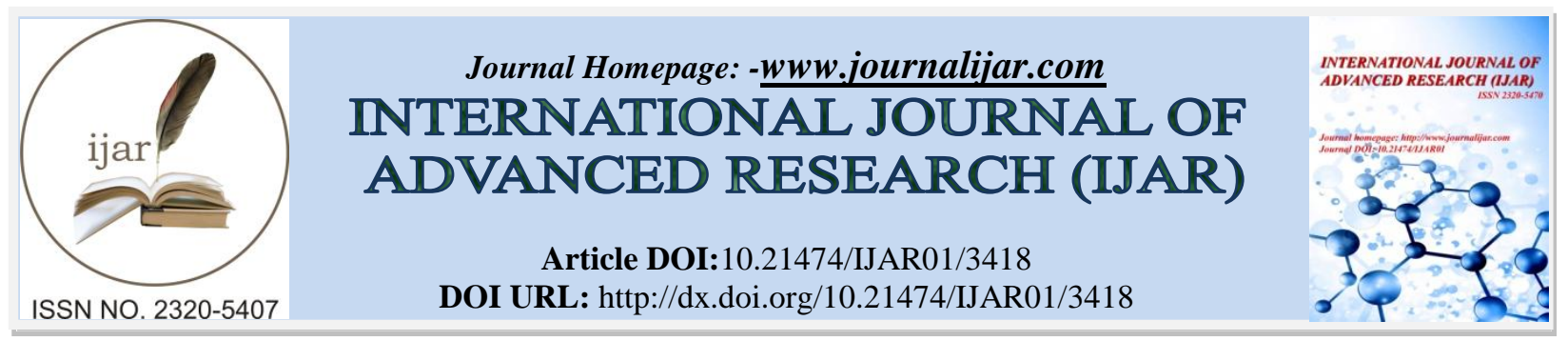

RESEARCH ARTICLE

\title{
STUDY OF SUSTAINABLE DEVELOPMENT OF PUBLIC TRANSPORT SYSTEM IN MALANG, INDONESIA.
}

Roedy Susanto, Zaenal Fanani and Mukhammad Soleh. Magister of National Defense, Brawijaya. University.

\section{Manuscript Info}

Manuscript History

Received: 16 December 2016

Final Accepted: 15 January 2017

Published: February 2017

Key words:-

Public transportation system, economy, traffic

\begin{abstract}
Malang is a college city and inhabited of approximately 1 million dwellers, dominated by productive ages. The domination of the productive age makes the movement of people in Malang is quite active. The thing is, Malang is not provided adequate public transportation system to support the movement of people. The available systems which are still use are the old systems which developed in the 90s. It affected on the surge of private vehicles as a mode of transportation. The effects of private vehicles use are the traffic jam, inefficient fuel consumption, health problems, the increase of accidents number, and the high-cost economy. Therefore, Malang needs to develop better public transportations, which can resolve the problems. Moreover, the development of public transportation system needs to consider several problems which may arise such as the refusal by public transportation entrepreneurs that already exist, the drivers or people who feel aggrieved. Then the development must be sustained, accommodate the needs of stakeholders, and involves all of them. The expectation is, with the better public transportation system, Malang will become a comfortable city, healthier, safer, and the economic is increasing.
\end{abstract}

Copy Right, IJAR, 2017,. All rights reserved.

\section{Introduction:-}

Malang is located in mountainous areas with varied contour and a total area of $252.1 \mathrm{~km} 2$. In Figure 1, Malang is the center of Malang Raya which included the city of Malang, Malang regency and Batu. As the central region, Malang is known as the city of education with more than 62 Universities and Academy schools, and hundreds of elementary, junior, and high school of public and private. It affects the rate of population growth in Malang and the people mobility.

As we see the development of the population in Malang during 2000 is inhabited by approximately 756.982 residents with the growth rate of the population of $0.86 \%$ per year since 1990 . About 317.283 people or $42 \%$ are in the age between 20 to 49 years which have high mobility rate. Though the population distribution in each subdistrict is considerably high, ranging from 126,000 to 182,000 (Statistics, 2008). The number of Malang population grew to 820.243 in 2010 and projected to reach 845.973 in 2014, with a growth rate of $0.31 \%$ between 2010 and 2013 and 0.64 in 2013 and 2014 (Statistics, 2012) (Statistics, 2015). Nevertheless, it is not the absolute number, because the total students in both public and private universities in Malang, has reached approximately 300.000 
which the majority are not Malang natives. It gives a huge contribution towards the level traffic jam in Malang, especially as the center region, a lot of comer work in Malang.

Now the transportation needs in Malang are facilitated by the government, even the facilities in the road and public transportation. However, from year by year, there is a tendency that the use of private cars as the main transportation has increased. As shown in Figure 2, In 2007 the number of private vehicles are 255.485, and increased to 279.606 in 2008, then to 291.404 in 2010, to 463.785 in 2014, and become 487.859 in 2015. In each of period, the number of motorcycles has always been a majority in comparison with the car about 5:1. In Figure 2, it illustrates the public transportation, the total is 2.758 in 2007 , decreased to 2.466 in 2008 , then slightly up to 2,527 in 2010, increased again to 2,659 in 2014 and eventually fell to 2,606 in 2015 (Statistics, 2008) (Statistics, 2013) (Statistics, 2015). Furthermore, based on the interview result with the Department of Transportation, in 2016, from 2.606 vehicles, only $70 \%$ of them are active, while the rest are not operating due to regulatory and feasibility reasons. Based on the existing data, it may indicate that the concern towards the public transportation has not been the main priority. Instead of increasing the number of fleets, the fact is if it compares in between 2007 and 2015 the fleets are decreased. Another problem is, the road length and the type of class road in Malang are tend to remain constants. For comparison, in 2007 the length roads of Class I was $29.77 \mathrm{~km}$ and the roads in good condition are $119,7 \mathrm{~km}$, while in 2014 the roads of class I reminded 29,77 and roads in good condition are $137.3 \mathrm{~km}$ (Stats 2008) (Statistics, 2015).

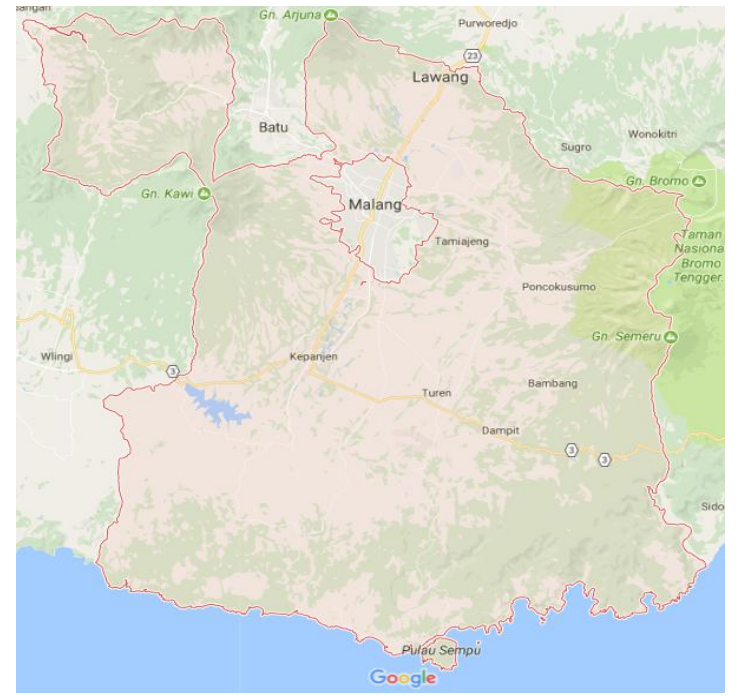

Figure 1:- Local Map of Malang (source: maps.google.com).

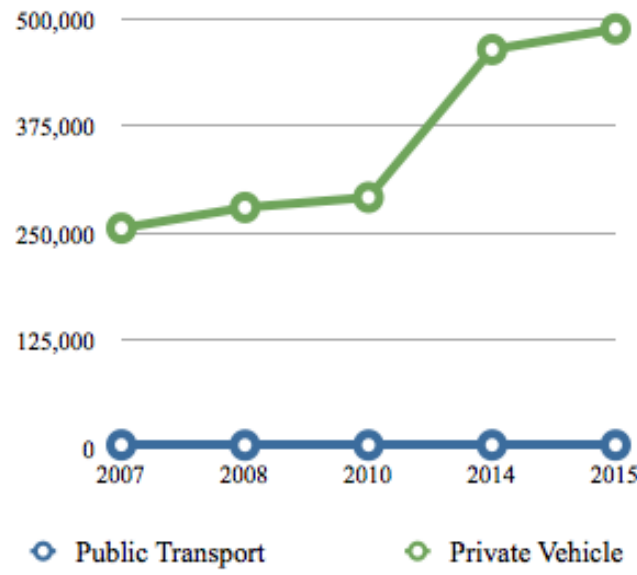

Figure 2:- The growth rate of private vehicles and public transportation. 
Along with these conditions, then the government is unavoidably obliged to organize a transport system which effective and efficient. Based on the explanation above, it requires a study of the development strategy in public transportation system in Malang. This paper will explain the condition of public transportation in Malang, from law and public policy of public transport perspective, the impact of public transportation, the stakeholder's need and recommendation of the development plan.

\section{Existing Public Transport Systems in Malang:-}

The public transportation in Malang is a minivan called microbus (mikrolet) with passenger capacity of 11 up to 14 , see Figure 3 as an illustration. There are two sit positions in a microbus, the first is one chair next to the driver, while the rest sitting face to face behind the driver chair as illustrated in Figure 4. The small size of the microbus allows it to sneak to narrow streets in Malang but the small room capacity for passengers make the loading and unloading process quite difficult and it makes the microbus inefficient as mass transit. Another disadvantage of microbus is related to the passengers' safety and comfort.

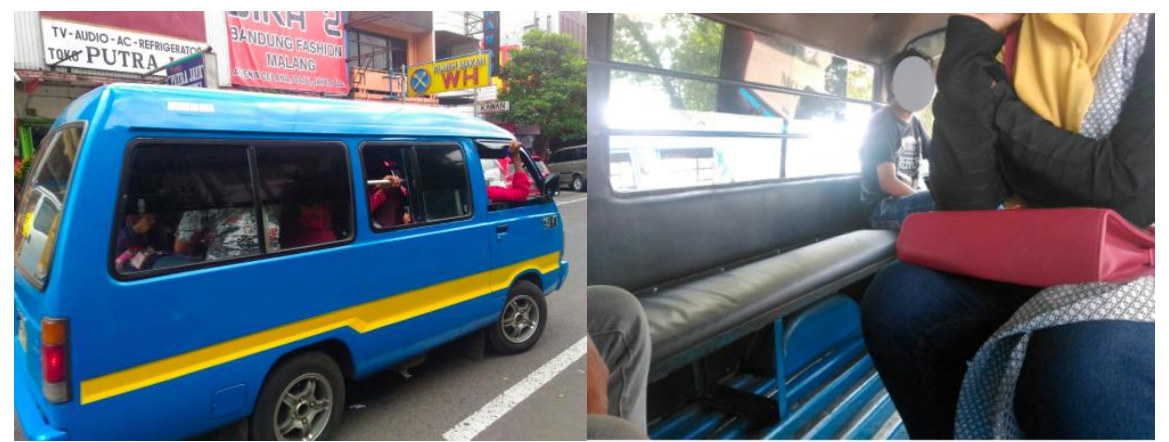

Figure 3:- Public transportation in Malang (Microbus/Mikrolet).

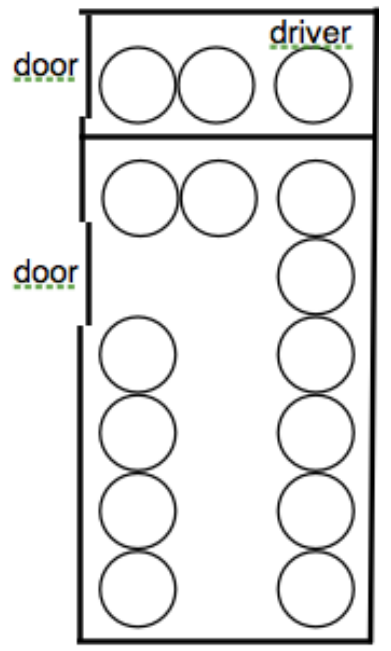

Figure 4:- Microbus seats layout

In accordance with the rules of government, public transportation can be managed by state-owned enterprises, region-owned enterprises, joint-stock company, and a cooperative only. In Malang, the management of public transport is coordinated by several cooperatives owned by Department of Cooperatives. Under these cooperatives, there are microbus owners who employ drivers to run the microbus.

The supervision of the functions of microbus is conducted periodically by the Department of Transportation of Malang. Elements such as comfort and roadworthiness are examined through this supervision. Types of the test conducted are such as gas superficial, lamps, side slip, head light, brake, and speedometer. According to Sugianto et al., 2013, Department of Transportation of Malang already has professional staffs and adequate equipment. Meanwhile, the problem is there are no enough workers, so the testing process tends to delayed. The delayed of this 
testing process resulted in microbus touts who attempt to quicken and manipulate the test process. This issue will definitely harm the users of public transportation and others drivers in terms of comfort and safety.

In Malang, the microbus divided into 25 routes, where each route connects a terminal with another terminal or certain area with another area. The path of each route may intersect each other, so the changing of the path may occur. The presence of terminals is intended as a place for microbus and public transport users. However, sometimes the development of infrastructure such terminals are not considered properly which resulted in the minimum providing of benefits. Take example the construction of Hamid Rusdi terminal which not functions properly because of its location which quite far from settlements and public service area. Furthermore, Hamid Rusdi terminal is indicated as one of traffic jam causes in other areas (Adhitama\& Hanafi, 2014).

To provide the guarantee of comfort, aside from periodic testing, Malang government also seeks to improve the condition of existing microbus. It is secured by the Regional Regulation no. 5 of 2011 on the rejuvenation of public transport. This is reasonable because the public transportation which operates is from 90's era, it is not convenient to use and the operational cost tends to high. Nevertheless, the process of rejuvenation did not take place until today because the financing is fully borne by the owners of public transport and it is disadvantaging them economically (Putri, 2013).

Under these conditions, for the purposes of the development of public transport in Malang, it is necessary to do a comparative study to determine the condition and the proper strategy. One of the studies which can be used a reference is the development of marine transportation system in Nusa Peninda, where their development objectives are to facilitate tourism activities in Bali and increasing the income of local people. In order to success in the development, it is necessary to involve local people and relevant institutions, infrastructure development, network, and transport support (Adnyana, 2016).

Furthermore, another study which can be used as a reference is a research by Rahma, 2013, about the performance of Department of Transportation of Malang and its functions as a regulator, facilitator, and evaluator of public transport systems, as well as the support factors and inhibiting factors of public transport in Malang. In the research, the evaluative and quantitative studies were conducted in order to get feedback from people about the level of satisfaction and dissatisfaction toward the performance of provided parameters.

Another similar study in a more comprehensive analysis is The Characteristics of the development challenge of public transportation in the Federal Capital Territory (FCT), Nigeria (Femi, 2012). Problem encountered in the FCT is the lack of government participation in performing the managerial function of the transport system. In the study, is advisable to establish a special authority to regulate the transport system in the FCT.

\section{Finding:-}

In the development of the public transportation system, the replicated on many factors is needed such from law, public policy, the impact of public transport, social and societal. All these factors are critical for ensuring the development plan made can be carried out smoothly without any conflict and other obstacles. The following is a discussion of these factors.

\section{The Warranty Law of Public Transport System:-}

Due to the traffic jam problem in Malang, serious efforts of Central and Local Government are crucially needed in the attempt to develop and plan the public transportation for mobilization of citizens. One of the efforts which already realized by the Central Government through Regulations No. 22 year 2009 until this time only in terms of signs for existed system settings which are about stations, the registration for public transports, and its treatment. There are no special instructions for plan and development toward the better way. Likewise, Malang Government did the similar efforts by means of Malang City Local Regulation No. 9 year 2006 which is replaced by Malang City Local Regulation No. 5 year 2011. The regulation only covers about the definition of public transportation, the requirements, and responsibility of its executant, transport procedures, and the responsibility of Government only on the surveillance level and taking action on any possible violation. In that regulation, Local Government does not indicate anything about how public transportation in Malang City will be developed.

The Warranty Law is vitally needed in order to provide certainty of the implementation of the developed public transportation. In that law, instruction related to the development of public transportation system which fulfills the 
principle of punctuality, low-cost, and has high certainty is being proposed. The pattern of Malang public transportation development is indeed has to consider the condition of Malang Raya and all the involved stakeholders. Direct adoption of deemed successful system in other cities such as Jakarta and Surabaya is uncertain of success if it is applied in Malang.

The Transportation Policy in Malang City Analysis of Public;-

As explained previously, public transports in Malang are subject to regulation defined in Local Regulation No.5 year 2011 about transportation in street with public motor vehicles. The regulation is organized into 2 parts, 13 chapters, and 32 subsections, and filled with signs and rules about:

1. Executant and public transportation service,

2. The permit of transportation business,

3. Routes,

4. Opening, modification, nullification of routes,

5. Driver liability,

6. Rights and obligations of passengers,

7. Technical requirements and roadworthy,

8. Provision of Retribution,

9. Surveillance,

10. Criminal provision,

11. Transitional provision,

12. Closing provision,

In this regulation, there are no explanations related to the plan and development of public transportation in Malang. It is mostly about the procedures of public transports management and penalties which will be given if rules are violated. Modes of arranged transportation are also limited to public transports with the maximum capacity of 8 passengers. Rights and obligations of both passengers and drivers are just set up a little. Ironically in that regulation, no warranty towards the rights of passengers is stated, because of the existed penalties are only on the matter of licensing administratively, incompatibility of vehicle condition by means of regulations. Whereas Government only steps in just to keep an eye on and assigns punishment if a violation happened. The government has no rights on settings and development on that regulation.

Furthermore, basically, Local Government through Department of Transportation has already stated Strategic Plan (Renstra) year 2014-2018 in which it is refined with Strategic Plan Alteration (Renstra) year 2014-2018 (Perhubungan, 2015), and one of the discussion is about public transportation. In this regard, Department of Transportation has identified the possibility of service development in form of mass transports like a city bus, school bus along with the increase of public transport safety factor. Moreover, management of traffic engineering and highway facility in every District in an attempt to make the highway users feel comfortable and safe has been planned as well. However, there is no strategic and tactical plan about how the development will be done and how the safety will be increased. The program of Department of Transportation related to public transports only covers the improvement of public transport service which involves:

1. Quality improvement of safe and comfortable service,

2. The improvement of coordination towards public transport businessman / Organda (Organization for public transport),

3. Socialization on public transport businessman on route,

4. Socialization on public transport drivers and pedicaps (becak),

Along with this condition, it can be predicted in coming years, the traffic conditions and public transport service will not have any improvement. Therefore, Local Government needs to realize the importance of development in this sector.

The Impact Analysis of Public Transport System:-

Nowadays, it can be said that the availability of public transport system in Malang does not fulfill the needs of transport maximally. It affects the increase of number and user of private vehicles as the main transportation. The direct consequences of this problem are the more severe traffic jam and the emergence of problems in safety sector. 
Traffic jam is a common issue which happened these recent years. The effort of government in the attempt to fix the quality and highways area will not be able to compensate the growth of private vehicle users. The direct consequence of this condition is in the environment problem, where the quantity of fuel consumption will always increase and the quality of life of society will go down. Traffic jam is also influenced by the driving characteristic of two-wheeled vehicle users which are dominated by young population. Indiscipline of this group towards the traffic regulations is frequently worsening the traffic jam. Another factor which is not directly linked to the public transport system but contributed in traffic jam is the lack of availability of pedestrian. People tend to use private vehicle rather than walking for short distance transport for safety reason.

In safety sector, there is an issue of thuggery which associated with the parking area. The number of vehicles which increase every year is not balanced with the adequate parking area. This cause the parking of private vehicles placed along the roadside which impact on the highway area. Parking areas along the roadside are generally managed by non-government parties that dominate particular areas illegally. As an illustration, illegal parking in Malang is shown by Figure 5 .

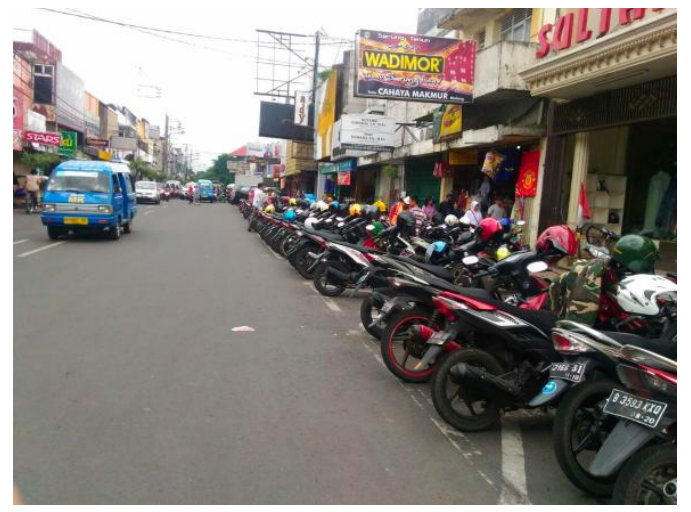

Figure 5:- Illegal Parking

The issues that exist today will be addressed with little conflict by a good public transport system. Firstly, the good public transportation will reduce the number of private vehicles. This will have a positive impact on environmental issues and reduce stress levels of people because of the traffic jam. Secondly, the decreasing number of private vehicles will reduce parking problems. It is possible that the area of the highway which decreases because of illegal parking will not occur again and the issue of safety which causes by the seizure of parking territory will be resolved.

\section{Needs Analysis of the Stakeholders:-}

The needs of stakeholders need to be considered with the aim to develop public transport policy in Malang. Malang is a unique city, in contrast with other major cities in Indonesia. Today, Malang has approached the concept of a metropolitan city which needs different considerations in developing the public transportation. The needs of stakeholders such Government, entrepreneurs, public transport drivers, and the users of public transport will be explained below.

\section{Government of Malang needs:-}

Based on the Strategic Plan 2014 - 208 Department of Transportation (Transportation, 2015), Malang faces traffic problems that quite complicated. The details of these problems are:

1. The rapid population growth.

2. The traffic jams in almost every roads.

3. High air pollution due to the large volume of vehicles.

4. Parking structuring which uncontrolled and less secure.

5. The undisciplined drivers.

6. Supporting facilities of the highway are inadequate.

7. Roads that not increase, while the number of vehicles increases rapidly.

8. Low coordination between SKPD (Work Unit area) which associate with the transportation.

9. Limited budget funds of the development and provision of facilities and infrastructure. 
In this case, we can conclude that the most important needs of Government of Malang which relate to the development of public transportation are:

1. Availability of integrated plan of public transportation development which can guarantee the people needs on public transportation.

2. The conducted development must consider the stakeholders needs so that there will be no party that feels aggrieved.

3. The development costs should be minimized, yet can provide effective and efficient results.

The needs of entrepreneur and the driver of public transportation:-

Public transport entrepreneurs are the owners of public vehicles which have a business license and appropriate route which compatible with the type of the public vehicles. In general, the driver can be included as the stakeholder because they work as employees of public transports entrepreneurs or the entrepreneurs may double as a driver too. Thus, the needs of public transport entrepreneurs and their drivers in the development of the public transportation system are:

1. The guarantee of business so that the income of the entrepreneurs of public transportation will not be disrupted.

2. The guaranteed job for drivers so that the income can be guaranteed as well.

3. Entrepreneurs of public transport need to be involved in the rejuvenation of public transportation or even the provision of new transportation modes.

4. The ease in administrative matters.

With the fulfillment of these requirements, then the possibility of rejection of the new system can be minimized.

\section{The Needs of Public Transport Users:-}

The people needs of public transportation are quite simple, which is convenient, on time and predictable, fixed path and cheap. If those requirements can be fulfilled, it is possible that the private vehicle users will switch to public transport.

The concern in Malang is the cost of public transportation which relatively high is indicated as the cause of the switching users from public transportation to private transportation. Today, public transport fare is Rp. 4.000,- for one route, so the return trip would cost Rp. 8.000,-. However, if the public transport users must change some routes, then the cost of round trip could reach Rp. 16.000,- or more. The use of private vehicles such as motorcycles are definitely cheaper, with the same expenditure can be used for two or more roundtrip.

Another need is on time and predictable schedule. In general, the public transport depart from the origin terminal to the destination terminal with two patterns, leaving with full of passengers or no passengers at all. For vehicles which depart in full of passengers, they will wait until the vehicle completely filled with passengers at the origin terminal without specified time limit. While the vehicle which departs with small occupancy will run on low speed for transporting the passengers along the way. Sometimes they will also stop at a certain location to wait for passengers and this cause on uncertainty on travel time and it is impossible to predict the travel time.

Another problem faced by users of public transport is, there is no guarantee of the availability of public transportation and arrive at the destination. At certain hours, public transportation decided to not operating because of the passengers is minimum. Public transportation may also do not pass the proper path in order to save the fuel and avoid the traffic jams or even because unwilling to take passengers to the destination terminal for the same reason.

The switching of public transportation users to private vehicles might also cause by the convenient factor. Some factors such as small size and difficult in access make public transportations give a less comfortable feeling.

\section{Result and Discussion:-}

By doing an analysis of the condition about the constant availability of roads while the number of private vehicles users is increased rapidly and the number of public transportations which tend to decrease, then in the future, Malang will certainly be trapped on the chaos traffic system. Before that problem occurs, it is better for the Government of Malang to start to make a plan for the development of public transportation which can mobilize the people quickly in large number yet low cost. Be aware that the current modes of transportation are inadequate and cannot fulfill the needs of people. Indeed the development is expensive, yet needs to find an effective way which involves all the stakeholders so that the usage of government funds can be minimized. Besides, the government of 
Malang and also the regional council of Malang are obligate in making rules \& laws to ensure the implementation of plan of the public transportation developments.

Another important thing that should be considered is the participations of the owners of public transportation and the drivers in the development's plans. Hopefully, the development will not make drivers lose their job and their income while the owners lose their business, and even better if the development could increase their income. Basically, the increasing of income is not an impossible thing because the potential of public transportation users is in massive number. The policy which involved the public transportation owners and the drivers could avoid the disapproval and social problem.

All of this means nothing if the needs of public transportation users are not accommodated as well. When the users satisfied with the quality of the service, where they can predict the duration of the trip, the punctuality, departure, and the arrival, the cost and also the convenient, then it is clear evidence of the governments' successes. Another success indicator is if the number of public transportation users could rapidly increase and the number of private vehicle users is decreased along with the decreasing of traffic jam ratio.

Therefore, the two scenarios that could be done in order to implement the development of public transportation successfully as well as satisfy all of the stakeholders are:

\section{Scenario 1:- Types of public transportation nowadays:-}

1. Private transportation revitalization, so all 2.606 microbuses could be operated

2. Adding of vehicles in every path

3. Extra subsidies for rejuvenation of vehicles

4. Adding of vehicles might result in decreasing of drivers' income, so there should be a subsidy for free hours.

5. The subsidy given is for on time public transportation on the departure and the arrival. It is important to give guarantee of duration for users.

6. There must be users' cost subsidy, so they will attracted to use public transportation

7. It is necessary to consider about the price for the duration trip rather than the amount of route which is used. For example, price for 2-hour trip is Rp. 4.000, if the public transportation users move the route within those 2 hours, there will be no additional cost. This idea could be use in electronic recording and payment system.

8. It is necessary to implement the application such as, Near Angkot (Hariyanto, 2015) which used by the users for monitoring public transportation that they want to use. Toward this application, the users could choose which route they want, see the amount of passengers, and monitoring its position. Meanwhile, the drivers may see the position of their passengers. Further, this application could be use as performance report of public transportation.

\section{Scenario 2: Type of public transportation which modified into bigger capacity:-}

1. There must be infrastructure which support the new type of transportation It is necessary to prepare a fixed bus stops and special system that can guarantee the passengers load and unload in the specified the bus stops.

2. The public transportation owners are associated in a company with share investment system, so that they could see their involvement in public transportation business

3. It is necessary to do data collection of drivers and make them as the employee of the company. This idea will advantage in reducing all sorts of upheavals that may arise and provide solutions on their income source.

4. The new transportation modes should have fixed schedule and also able to provide certain duration trip and departure.

5. The cheap cost should be the main priority, the convenient of the passengers and also sufficient quantities of passengers

The transportation modes which not expensive is a medium bus with 28 passengers or a bigger bus with 40 passengers. Better if using the Bus with electrical power like a tram, because it does not produce gas emissions.

\section{Conclusion:-}

Today, the government of Malang does not have plans to develop the public transportation system yet. Whereas in the short future, the traffic jam in Malang could be worst because the increasing of private vehicle users while the number of roads are constant. Therefore, the government of Malang needs to make a strategic plan to develop the public transportation which is boosted by regional regulations which binding. In the implementation, this 
development must consider the needs of all stakeholders and involved all stakeholders. There are two suggestions development, those are; maintain or remodel the types of the transportation. Yet both of it have the same goals which are given the service guarantee toward public transportation users as well as involved the owners of public transportation and the drivers also. All in all, this idea will solve the traffic jam in Malang as well as avoid the possibilities of conflict.

\section{References:-}

1. Adhitama, M.O. and Hanafi, I., 2014. "DampakKebijakan Pembangunan Infrastruktur Di Kota Malang". Reformasi, 4(1).

2. Adnyana, I. B. P., 2016. "The Development of Marine Transportation System in Supporting Sustainable Tourism Case Study: Nusa Penida Island, Bali Indonesia.” Journal of Sustainable Development, 9(4), 89.

3. Femi, S. A. G., 2012. Characterization of Current Transportation Challenges in the Federal Capital Territory, Nigeria. Journal of Sustainable Development,5(12), 117.

4. Hariyanto, W., 2015. Aplikasi. "Near Angkot" Berbasis Android SebagaiSaranaPencarianAngkotTerdekat Di Kota Malang. University of Muhammadiyah Malang.

5. Perhubungan, D., 2015. PerubahanRencanaStrategisTahun 2014-2015. DinasPerhubungan Kota Malang, Malang.

6. Putri, E.H., 2013. "EvaluasiKebijakanPeremajaanAngkutan Kota DalamUpayaPeningkatanPelayananPublik (StudipadaDinasPerhubungan Kota Malang)". JurnalAdministrasiPublik, 1(3), pp.87-93.

7. Rahma, N., 2013. "PerananDinasPerhubungandalamMeningkatkanPelayananMasyarakat di BidangAngkutan Kota (StudipadaDinasPerhubungan Kota Malang)". JurnalAdministrasiPublik, 1(7), pp.1296-1304.

8. Statistik, B.P., 2008. Kabupaten Malang DalamAngkaTahun 2008. BadanPusatStatistikKabupaten Malang, Malang.

9. Statistik, B.P., 2012. Kabupaten Malang DalamAngkaTahun 2012. BadanPusatStatistikKabupaten Malang, Malang.

10. Statistik, B.P., 2015. Kabupaten Malang DalamAngkaTahun 2015. BadanPusatStatistikKabupaten Malang, Malang.

11. Sugianto, A.H., 2013. "EvaluasiKinerjaPelayananDinasPerhubunganDalamBidangAngkutanUmumPerkotaan (StudiPadaDinasPerhubungan Kota Malang ProvinsiJawaTimur)". Jurnal of Public Administration Research, $1(1)$. 